\title{
内側足底皮弁を用いた足底荷重部皮膚欠損の再建
}

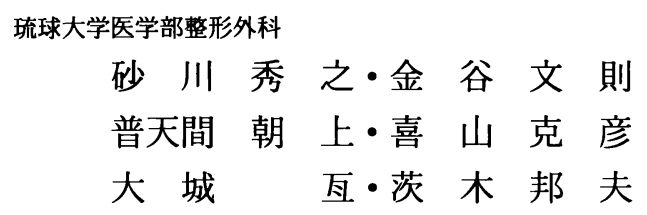

\section{Medial Plantar Flap for Skin Defects of the Weight-bearing Area of the Foot}

\author{
Hideyuki Sunagawa, Fuminori Kanaya, Chojo Futenma, \\ Katsuhiko Kiyama, Wataru Oshiro, and Kunio Ibaraki \\ Department of Orthopedic Surgery, School of Medicine, \\ University of the Ryukyus, Okinawa, Japan
}

The weight-bearing area of the foot is covered by thick, stable, and tough glabrous skin. In 6 patients, we covered the skin defect of the weight-bearing area with either pedicle or free medial plantar flaps. The patients' age ranged from 16 to 55 years old (mean 34 years old). Skin defects were located at the forefoot in 3 and at the heel in 3 . The size of the flaps ranged from $6.5 \times 5 \mathrm{~cm}$ to $16 \times 10 \mathrm{~cm}$. There were 5 free vascularized flaps and 1 pedicle flap. In 2 free flaps, nerve to medial plantar skin was not repaired. All flaps survived completely and 5 out of 6 flaps recovered some sensation. One patient who did not recover sensation in the free medial plantar flap produced ulcers at 2 years and 3 years- 2 months after surgery. These ulcers healed without sequele recurrence after debridement and closure.

We think that the medial plantar flap is the treatment of choice for the coverage of weightbearing area, and sensory recovery is needed to prevent ulcer formation.

Key words : medial plantar flap (内側足底皮弁), weight-bearing area (荷重部), sensory flap (知覚 皮弁)

\section{はじめに}

足底部の皮膚は, 荷重に適した特殊な構造をしてお り，同部位の皮唐欠損に対し有毛部からの植皮や皮弁 を行うと潰瘍を形成しやすい ${ }^{11}$. 内側足底皮弁は足底 非荷重部のつちふまず部の皮弁であるため恵皮部の障 害が少なく，また知覚皮弁とすることも可能である2． 私たちは足底荷重部皮唐欠損に対して内側足底皮弁に よる再建を行ない，良好な結果を得たので報告する。
対

象

症例は 6 例で, 全例男性であり, 手術時年齢は 16〜55才（平均 34 才）であった. 欠損部位は前足部 が 3 例, 踵部が 3 例で, 原因は交通事故が 3 例と最も 多く, 落下した材木による圧挫, ローラーによる圧挫, 悪性腫瘍切除後が各々 1 例であった。

内側足底皮弁の大きさは最小 $6.5 \times 5 \mathrm{~cm}$ 最大 $16 \times$ $10 \mathrm{~cm}$ であった．遊離皮弁は 5 例でうち 3 例に神経縫 合を行い, 有茎皮弁の 1 例では皮弁に知覚枝を含めた (表 1). 


\begin{tabular}{|c|c|c|c|c|c|c|c|c|}
\hline 症例 & 年齢 & 原因 & 診断 & 欠損部位 & 皮弁の分類 & $\begin{array}{l}\text { 皮弁の大きさ } \\
(\mathrm{cm})\end{array}$ & $\begin{array}{c}\text { 知覚・ } \\
\text { S-W test }\end{array}$ & 潰瘍形成 \\
\hline 1 & 29 & 交通事故 & 左足部剥皮創 & 踵部 & 遊離 & $11 \times 11$ & $+\cdot 4.31$ & - \\
\hline 2 & 52 & 悪性黒色腫 & 悪性黒色腫 & 踵部 & 有茎 - 知覚 & $10 \times 8$ & $+\cdot 6.45$ & - \\
\hline 3 & 55 & 材木で圧挫 & 右足不全切断 & 前足部 & 遊離 - 知覚 & $9 \times 6$ & $-\cdot>6.65$ & + \\
\hline 4 & 27 & 交通事故 & 左母趾切断 & 前足部 & 遊離 - 知覚 & $6.5 \times 5$ & +・非測定 & - \\
\hline 5 & 26 & 交通事故 & 左足部剥皮創 & 踵部 & 遊離 - 知覚 & $16 \times 10$ & $+\cdot 4.31$ & - \\
\hline 6 & 16 & ローラーで圧挫 & 右前足部圧挫創 & 前足部 & 遊離 & $11 \times 8$ & +・非測定 & - \\
\hline
\end{tabular}

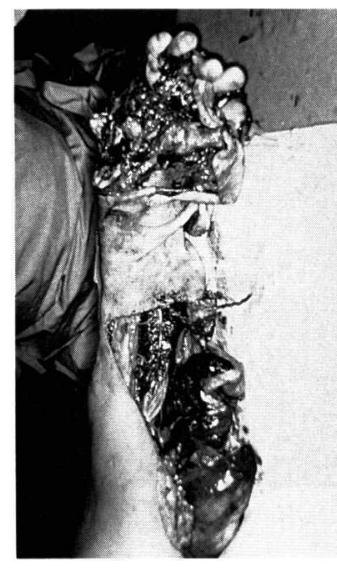

A

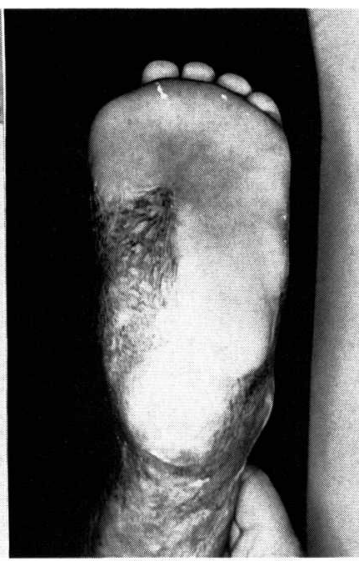

B

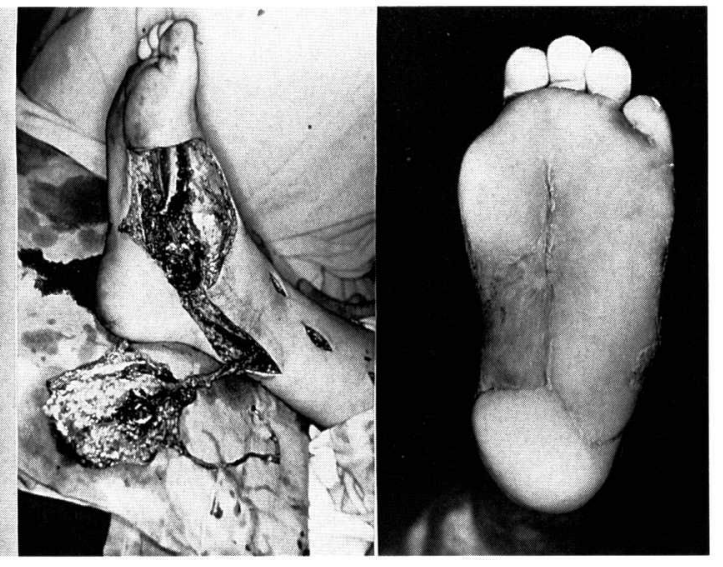

C

D

図 1 症例 $1 ： 29$ 才男性. バイク事故で, バスのタイヤの下敷きとなり受傷
A. 左下腿〜足部の剥皮創, 左足部開放骨折
B. 受傷後 2 年, 踵部は瘷痕化し潰瘍を反復
C. 健側加ら $11 \times 11 \mathrm{~cm}$ の遊離内側足底皮弁を採取
D. 皮弁は完全生着し, 術後 8 年 2 か月で潰瘍形成を認めず歩行時痛もない

術後観察期間は 1 年 11 力月 8 年 3 力月（平均 3 年 5 カ月) であった.

$$
\text { 結 果 }
$$

全例完全生着した，遊離皮弁に神経縫合を行った 3 例中 2 例と有茎知覚皮弁の 1 例および神経縫合を行わ なかった 2 例で, ある程度の知覚が回復し, これらの 例には潰瘍形成を認めなかった。受傷後 18 年で遊離 知覚皮弁を行った 1 例で知覚回復を認めず術後潰瘍を 形成した.

\section{症例}

【症例 $1 】 29$ 才男性.

昭和 63 年バイク事故で左下腿から足部にかけての 剥皮創，左足部開放骨折を受傷した。近医にてデブリ
ドマン，骨接合術が施行された。その後下腿から足部 の剥皮創が壊死となり 2 回の植皮が行われたが踵部は 生着せず㗪痕化し，潰瘍を繰り返した。受傷後 2 年で 踵部の被覆目的のため当科入院となった。患側踵部の 㿍痕を切除し, 健側から採取した $11 \times 11 \mathrm{~cm}$ の遊離 内側足底皮弁により被覆した。皮弁は完全生着し, 術 後 8 年 2 力月では潰瘍形成を認めず, 歩行時痛の訴え あなかった. 知覚は Semmes-Weinstein test（以下 S-Wtest） 4.31 と protective sensation であった (図1).

【症例 2 】 2 才男性.

平成 4 年左踵部の黒色斑に気付いたが痛みがないた め放置していた。平成 8 年当院皮膚科にて悪性黒色腫 之診断され，切除後の再建を目的として当科紹介され た. 初診時, 左踵部に $2 \times 2 \mathrm{~cm}$ の悪性黒色腫を認め 


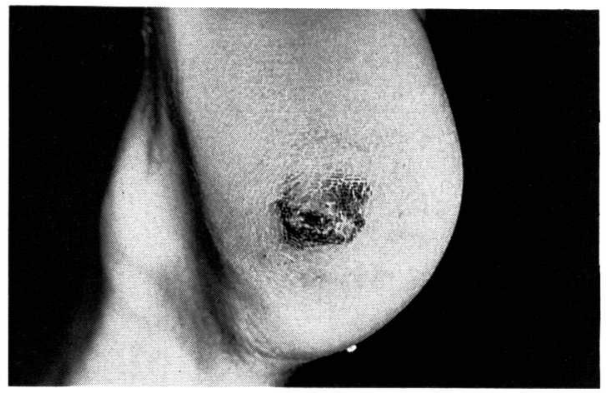

A
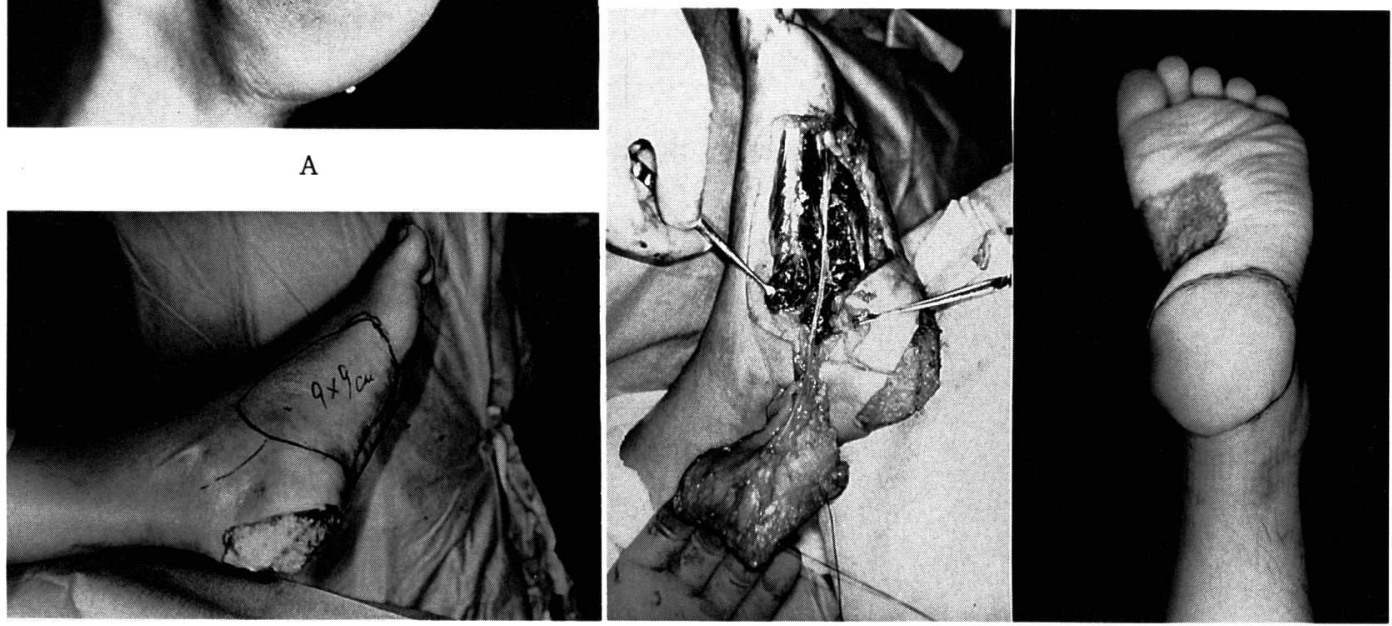

B

C

D

図 2 症例 $2: 52$ 才 男性. 左踵部悪性黒色腫
A. 左踵部に $2 \times 2 \mathrm{~cm}$ の悪性黒色腫
B. 広範切除後の欠損部之皮弁のデザイン
C. 同側より内側足底皮弁を有茎知覚皮弁として挙上
D. 皮弁は完全生着し, 術後 2 年で悪性黒色腫の再発を認めず歩行時痛むない

た. 皮膚科にて広範切除後, 欠損部を同側より有茎知 覚皮弁として挙上した $9 \times 9 \mathrm{~cm}$ の内側足底皮弁で被 覆した. 皮弁は完全生着し, 術後 2 年の現在, 覀性黒 色腫の再発を認めず, 歩行時痛むない. 皮弁の知覚は S-W test では皮弁が 6.45 と健側と同值を示した（図 2 ).

【症例 3 】5 歳男性.

昭和 51 年右前足部に材木が落下し不全切断を受傷 した. 当科にてリスフラン関節離断後, 断端を遊離崢 径皮弁で被覆したが, その後, 移植した単径皮弁部に 18 年間で潰瘍を約 40 回繰り返した. 前足部のデブリ ドマン後, 健側より採取した $9 \times 6 \mathrm{~cm}$ の遊離内側足 底知覚皮弁で被覆した. 皮弁は完全生着したが知覚が 回復せず, 術後 2 年および 3 年 2 力月時に皮弁部に潰 瘍を形成したが，いずれもデブリドマンのみで治癒し た.
考 察

足底部の皮膚は可動性が少なく, 厚い無毛皮膚 （glabrous skin）であり, 荷重に対して耐圧性がある. 一方, 有毛皮膚は耐圧性がなく, 足底部の皮膚欠損に 対して有毛皮膚の植皮や皮弁を行うと潰瘍が形成され やすい1). 内側足底皮弁は非荷重部の無毛皮膚で，採 取後の影響が少ないこと, 知覚皮弁として採取可能な こと，また同側では有茎皮弁として挙上可能なことか $ら^{2)}$, 足底荷重部の再建に適していると思われる.

小林ら ${ }^{2)}$ は内側足底皮弁による足部の被覆再建を 50 例に行い, 症例数は不明だが知覚が回復した症例 に潰瘍の形成はなく, 知覚が回復しなかった症例では 潰瘍を形成した症例があったことから，知覚再建が重 要と報告した。一方, 高松ら ${ }^{3)}$ は遊離肩甲皮弁による 足底再建を 10 例に行い 3 例に潰瘍形成を認めたがそ 
のうち 2 例は知覚回復例であり, 知覚の回復と潰瘍形 成には相関は認めなかったと報告した．私たちは，足 底皮席欠損術後の潰瘍形成を予防するためには, 同部 を無毛皮唐で覆うことが重要と考えているが，知覚が 回復しなかった 1 例のみで潰瘍を形成した結果から知 覚再建も必要と考える.なおこの 1 例は受傷後 18 年 で遊離知覚皮弁を行ったが知覚回復が全く得られず， この原因として近位神経の高度な変性が考えられた。

$$
\text { ま と め }
$$

1）足底荷重部皮席欠損 6 例に対して内側足底皮弁 による再建を行い全例完全生着した。
2 ）知覚が回復した 5 例に潰瘍の形成はなく，回復 しなかった 1 例のみで潰演の形成を認めた.

3 ）内側足底皮弁は足底荷重部皮席欠損の再建に有 用であり，知覚回復は潰瘍形成の防止に必要と考えら れた.

参 考 献

1）栗原邦弘ら：足底荷重部再建例の遠隔成績. 形成外科, $31: 714-726,1988$

2）小林誠一郎, 関口順輔 : 神経付き内側足底皮弁. 形成 外科, $33: 1061-1069,1990$.

3）高松亜子ら：遊離肩甲皮弁による足底再建の長期経過 観察. 形成外科, $37: 1137-1144,1994$. 